\title{
Online-Based Transportation Business Competition Model of Gojek and Grab
}

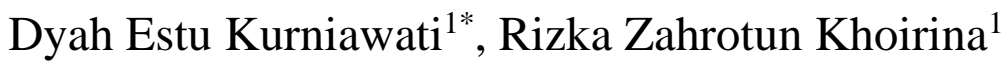

\author{
${ }^{1}$ Department of International Relations, University of Muhammadiyah Malang, Malang Indonesia \\ *Corresponding author. Email: dyahestu@umm.ac.id
}

\begin{abstract}
The transportation technology revolution has changed the lifestyle and power relations in business competition. The competition is not only between traditional transportation modes and online transportation modes, but also between online transportation business actors themselves. This paper addressed to analyzed the competition of Grab and Gojek, the two decacorns) in a collaborative economic era. Data is collected through surveys, documentation studies, and interviews with business competitors and service users. Data analysis is descriptive-analytic. The analysis uses the concept of business competition with political economy dimension. The results of this study indicate that the competitive model of online-based transportation business carried out by taking and driving through price wars and promotions is also needed to collaborate with various parties. Collaboration carried out not only with local governments but also nongovernmental organizations. The aim is not only to contribute to the improvement of people's welfare in accordance with the government's request but also to secure their business.
\end{abstract}

Keywords: online-based transportation, competition model, collaborative economy, neoliberalism

\section{INTRODUCTION}

The transportation technology revolution has changed the lifestyle and power relations in business competition. The competition is not only between traditional transportation modes and online transportation modes, but also between online transportation business actors themselves. The first problem seems to have not been completely resolved, apparently the second problem arises related to the relation of power between Grab and Gojek which has dominated the transportation sector in various regions, including in Malang Raya. The authors want to describe how the competition model between Grab and Gojek in providing transportation services to consumers.

\section{RESEARCH METHOD}

This research is a descriptive study using primary data types in the form of interviews with Grab-Gojek and goalkeeper managers in Malang and service users, as well as the government of Malang City. Secondary data in the form of publications in various media are also used by the writer to complete the data and enrich the analysis.

To analysis the business competition model between Grab and Gojek, this study uses the concept of Competition in the sharing economy which explains that competition in a sharing economic system is very dynamic [1].

In terms of history, the term sharing economy began to be popular in public media since the publication of a book by Botsman and Rogers on the rise of collaborative consumption. The terms "sharing economy", "collaborative consumption", "peer to peer economy" are popular terms to describe the phenomenon that occurs as a peer to peer division of access to underutilized goods and services. but the sharing economy has given a new perspective on the design of business models. New players like Airbnb are a small example of making use of the sharing economy. Airbnb has been in the world's leading international traditional hotel chain and is expanding smoothly. Sharing economy can be found in the past, namely sharing among family members and closest kin.

In early 2000, responding to growth in natural resource constraints, people began to use the internet to increase efficiency by connecting online and offline and sharing economy became an important part of this initiative. The practice of sharing economy was initially believed to be a franchise initiative and evolved into a big business model by taking a fraction of the cost of sharing [2]. The concept of sharing economy entered into public discourse between 2011 and 2012 with two successful Silicon Valley stories, Airbnb and Uber. In its development, scholars have coined different terms in capturing the various meanings of sharing economy based on their disciplinary background.

Basically, there is no clear definition of sharing economy. Some say that sharing economy is organized by the value that comes from assets that are not utilized and makes them accessible online by the community, which leads to a reduced need for ownership. Other opinions say that the sharing economy is the people who coordinate the acquisition and distribution of resources for other costs or compensation [3].

Although there is no definite definition what is a business model of sharing economy, there are several companies that use this business models such as Gojek and Grab. Division of players in business requests and offers through a platform. This business model provides a new economic paradigm that will create new challenges including in 
establishing a tax system, changing production models, productivity and the labor market. [4]

In general, this economic sharing has a positive impact on economic growth and prosperity by stimulating new consumption, improving the quality of innovation and entrepreneurship. Sharing economy becomes a business model that combines various aspects into one aspect to make it more accessible to the wider community, such as accommodation, mobility, goods, skills, clothing, food, knowledge \& employment, health, law, insurance, finance and services [5].

Very tight competition among economic sharing actors has inevitably brought new competition models that have led to collaborative efforts with various parties [6]. The Collaboration not only with their partners but also with the government and even non-governmental organizations. The aim is to maintain the sustainability of each party's business [7],[8]. Changing business relationships from competition to collaborative action is a new model of competition in the industrial era 4.0.[9]

\section{RESULTS AND DISCUSSION}

Sharing economy business model has also been implemented such as Grab and Gojek, which is the largest online transportation service mode in many regions in Indonesia. According to a survey from Spire Research and Consulting a leading global research company based in Tokyo, Japan, conducting studies on grab and gojek drivers and consumers, Jeffrey Bahar, Group Deputy CEO of Spire Research and Consulting, said the online transportation industry is flourishing in Indonesia. Many players appeared, but only two survived, namely Go-Jek, the unicorn start-up then become decacorn from Indonesia and Grab, the largest provider of online transportation services in Southeast Asia. Based on data from the Central Statistics Agency / PBS 2018, Indonesia's population reaches 265 million. This has become a special attraction for business people, especially in the transportation industry. Therefore, a very large population is clearly accompanied by high consumption and mobility needs.

Grab was first established in Malaysia and then expanded to Singapore, Thailand and the Philippines in 2013. In 2014 Grab was present in Vietnam and entered Indonesia. Until now Grab operates in 8 countries in the Southeast Asia region which includes Indonesia, Malaysia, Vietnam, Singapore, the Philippines, Thailand, Myanmar and Cambodia. competing with Grab, Gojek was first established in Indonesia in 2015 then expanded to Vietnam, Singapore, the Philippines and Thailand. In Vietnam sendri gojek comes with the name Goviet as a result of collaboration between the local Vietnamese team and gojek. in Indonesia, Gojek has existed in 167 cities and districts throughout Indonesia. while based on the 2018 report, Grab has expanded its business to 222 cities throughout Indonesia.

To support its business, Grab received injections of investment funds from several large companies such as Hyunday, Soft Bank, Toyota and $\mathrm{N}$ and several other companies. While Gojek was sponsored by several companies including TRC, SEQUOIA, Warburg Pincus,
Tencent, Rakuten, Google, Temasek and one large company from China and in addition from several other companies.

The competition for the business model of sharing economy in the two transportation service companies is to provide various services on one platform, namely the Grab application and the Gojek application. Both of them not only provide "ride hailing" services, but also fulfill ondemand services that offer a variety of services needed by the community ranging from shipping services, shopping services, massage services, makeup artists and cleaning services. Another thing that is "payment" payment solutions offered by each application. Gojek with go-pay and grab with grab-pay which then now works with OVO. Gojek registered 108 million apps downloads and claimed $50 \%$ of users use go-pay. While OVO there are 60 million apps downloaded. Previously in 2017, gojek had acquired "my cards", mitrans and established to strengthen its payment system, while in the same year, grab acquired udo, then grab also collaborated with banks and fintect in singapore, vietnam, malaysia, thailand. In the field of finance services, grab by cooperating with OVO plans to hold a number of financial services such as micro credit, insurance and savings. Neither do Gojak in collaboration with three peerto-peer landing companies such as findaya, joy, assets.

The competition between Grab and Gojek that implemented an economic sharing was very dynamic [10]. Not only competing with conventional modes of transportation, they also compete with each other to attract consumers' interest by providing good service at competitive prices, as well as providing attractive promos for their customers.

Although globally Grab and Gojek which have almost the same system almost simultaneously release the results of a survey that claims each is a market leader both in the online motorcycle taxi industry and in the food-delivery service industry, but based on field data between Grab and Gojek have several different things that are the advantages of each company.

This can be seen starting from the facilities provided that have been listed in the application in Grab and Gojek, rates, and promotions offered. Grab services perceived well by respondents are in terms of speed, while Gojek has more diverse facilities. In terms of prices offered by Grab, it is more attractive to consumers, while for Gojek items that are highly perceived are price fixes. In grab promotion, Grab looks more attractive to consumers than Gojek, and even Grab has put a promo on Grab anywhere where it only costs Rp. 1.00. But because of this program grab received a warning from the government related to unfair competition. From the results of interviews of writers with consumers of gojek and grab, since the government has warned that offers related to discounted prices from both gojek and grab have decreased. In fact, many consumers have complained about the more expensive go and grab rates [11]. To overcome this problem, Gojek and Grab have an interest in always

Grab uses the results of research released by Kantar to become the consumer preferences for the four largest application-based food market leaders in online messaging services in Indonesia, while delivery services in Indonesia. Gojek uses the results of Nielsen's Singapore research on Indonesian analyzing existing markets and regulations so there are no problems and making their business models 
sustainable. In its development, Gojek and Grab no longer rely too much on price discounts to attract more consumers, but rather on improving the quality of service [10].

The dynamics of Grab and Gojek competition to improve the quality of services for consumers and support the sustainability of their businesses encourage them to collaborate with all parties including local governments and non-governmental organizations. Their problem's not only competing with competitors but also need to pay attention to the efforts of conventional actors who often lobby the government to ban the practice of sharing economic businesses. This competition is expensive and can drain resources so that it requires various innovations in business competition, both in the form of services, prices, and promotions, as well as collaborative efforts with various parties includes government [6]. The sharing economy has been posited as a potentially significant contributor to the SDGs. Cohen (2016) suggests that truly "shared" noninternet mediated consumption is in decline, or is at the very least are being ignored, and is increasingly replaced with emergent collaborative economies in neoliberalism paradigm [8], [12].

Table 1. Gojek and Grab Collaborative Action

\begin{tabular}{|c|c|c|c|c|}
\hline \multirow{2}{*}{$\begin{array}{l}\text { Online } \\
\text { Transport } \\
\text { Company }\end{array}$} & \multicolumn{4}{|c|}{ Collaborative Action } \\
\hline & & Institution & $\begin{array}{c}\text { Proof } \\
\text { Agreement }\end{array}$ & Target \\
\hline Grab & $\begin{array}{l}\text { Local Government } \\
\text { Bandung }\end{array}$ & (Kota) & $\begin{array}{l}\text { The signing of } \\
\text { the } \\
\text { Cooperation } \\
\text { Agreement }\end{array}$ & $\begin{array}{l}\text { 1. Overcome the challenges of transportation in Indonesia. } \\
\text { 2. Maximizing the potential of the tourism, transportation, } \\
\text { environmental management and digital infrastructure } \\
\text { sectors. } \\
\text { 3. Bring jobs. } \\
\text { 4. Improve services in the field of public transportation }\end{array}$ \\
\hline Gojek & $\begin{array}{l}\text { Local Government } \\
\text { (Pemprof) West Java }\end{array}$ & $\begin{array}{l}\text { MoU } \\
\text { signed }\end{array}$ & & $\begin{array}{l}\text { 1. Gojek partner shelter which will be built in the Satay } \\
\text { building area, the center of West Java government. } \\
\text { the existence of coaching and development of small } \\
\text { businesses in Java by Gojek, training women for } \\
\text { empowerment, optimizing online transportation services } \\
\text { and using Go-Pay as a method of payment in locations } \\
\text { managed by the provincial government of Java. } \\
\text { 3. a number of trainings under the Entrepreneurial Goal to } \\
\text { empower the community } \\
\text { 4. Gojek accommodates female workers through many } \\
\text { Gojek }\end{array}$ \\
\hline Grab & Komnas Perempuan & & $\begin{array}{l}\text { Collaborative } \\
\text { agreement }\end{array}$ & $\begin{array}{l}\text { 1. Review SOP on handling women's cases and educating } \\
\text { messages on violence against women. antiviolence } \\
\text { against women workshop to driver partners, and access } \\
\text { to competent experts on women's issues. }\end{array}$ \\
\hline Gojek & $\begin{array}{l}\text { Local Government } \\
\text { Malang }\end{array}$ & & $\begin{array}{l}\text { Collaborative } \\
\text { agreement }\end{array}$ & $\begin{array}{l}\text { 1. Build the UMKM } \\
\text { 2. Help the development of the city towards smart digital } \\
\text { city. }\end{array}$ \\
\hline
\end{tabular}

However, there is a distinction between the sharing and the collaborative economy, in that sharing refers to predominantly private, and often non-commercial transactions, while the collaborative economy is focused on mediating commercial business-to-peer exchanges, virtually always involving platforms owned by global corporations. This has implications for the Sustainable Development Goals (SDGs), as the sharing economy may have promising outcomes for SDGs while the collaborative economy, which is increasingly shaped by neoliberal principles, does not advance these [13]. Collaboration carried out by decacorns to secure their business may become even more powerful for economic neoliberalism [12].

\section{CONCLUSION}

The competition business between Grab and Gojek in providing transportation services to consumers has shifted from a competitive to a collaborative model. The competition between Gojek and Grab revolves around offering more attractive prices or increasing the number of services to better meet the needs of its consumers. Because there are rules about business competition that do not allow unhealthy competition practices, efforts have emerged to secure the sustainability of their business through collaborative action. Collaborative actions are carried out not only with the government but with non-governmental organizations, such as those conducted by Gojek and Grab. Thus, the business competition model between Gojek and Grab has experienced a shift from competition to collaboration.

\section{ACKNOWLEDGMENT}

This research was supported by Research Block Grant of Faculty of Social and Political Science, University of Muhammadiyah Malang. 
of airbnb case in Spain and Portugal," J. Theor. Appl. Electron. Commer. Res., vol. 13, no. 3, pp. 85-98, 2018.

[8] A. Taeihagh, "Crowdsourcing, Sharing Economies and Development," J. Dev. Soc., vol. 33, no. 2, pp. 191-222, 2017.

[9] H. Antlöv, D. W. Brinkerhoff, and E. Rapp, “Civil Society Capacity Building for Democratic Reform:

Experience and Lessons from Indonesia," Voluntas, vol. 21, no. 3, pp. 417-439, 2010.

[10] B. Salim and J. J. O. I. Ihalauw, "Transformasi Model Bisnis Go-Jek Untuk Keunggulan-Kompetitif Dalam Perkembangan Ekonomi-Berbagi Dari Sudut Pandang Pelanggan," J. Bus. Appl. Manag., vol. 10, no. 02, pp. 106-123, 2017.

[11] K. V. Natalia, “Analisis Perbandingan Persepsi Kualitas Pelayanan, Harga Dan Kepuasan Konsumen Go-Jek Dan Grab,” 2018.

[12] A. Zwick, "Welcome to the Gig Economy: neoliberal economy and tourism: Critical perspectives, industrial relations and the case of Uber," questionable claims and silenced voices," Tour. GeoJournal, vol. 83, no. 4, pp. 679-691, 2018. Recreat. Res., vol. 40, no. 3, pp. 286-302, 2015.

[13] D. Dredge and S. Gyimóthy, "The collaborative
[7] P. R. Palos-Sanchez and M. B. Correia, "The collaborative economy based analysis of demand: Study
[6] S. Gössling and C. Michael Hall, "Sharing versus collaborative economy: how to align ICT developments and the SDGs in tourism?," J. Sustain. Tour., vol. 27, no. 1, pp. 74-96, 2019. 